\title{
Effects of Scenedesmus deserticola JD052 Extracts on UV-induced Skin Irritation
}

Jun Seok Baek, Se-eun Jin, Seung Hye Kang, Chansun Park, Jae Hoon Jeong, Sang Won Yi, Young Soo Kim* Material Sciences Research Institute, LABIO Co., Ltd., Seoul, Korea

*Corresponding author: Young Soo Kim, Material Sciences Research Institute, LABIO Co., Ltd., No.308-309, Gasan digital 2-ro, Geumcheon-gu, Seoul 08501, Korea

Tel.: +82 221130529

Fax: +82221130506

Email: msri13@labio.kr

Received July 31, 2017

Revised October 30, 2017

Accepted November 10, 2017

Published March 30, 2018

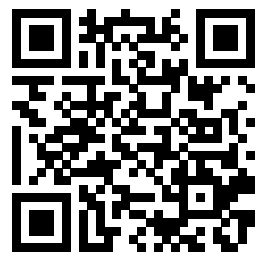

\begin{abstract}
Purpose: The aim of this clinical study was to evaluate the effects of toner, lotion, and cream containing Scenedesmus deserticola JD052 (JD052) extract on ultraviolet (UV) induced skin irritation, dermal density, facial wrinkles, and dermal moisture. Methods: 22 female volunteers over 29 years of age were selected on the basis of predetermined inclusion and exclusion criteria. Every morning and night for 4 weeks, each subject washed their face and left upper arm and then applied the same amount of each test material on these areas in the following sequence: toner, lotion, and cream. The following effects were then evaluated: the skin soothing effect on UV-induced skin irritation using a solar simulator and the ANTERA 3D Dermal Imaging Device; dermal density improvement using the DUB ${ }^{\circledR}$ SkinScanner; facial wrinkle improvement using the ANTERA 3D; and dermal moisture improvement using the MoistureMeterD Compact. Results: After 2 and 4 weeks, respectively, of application of the test materials, the $a^{*}$ value, which indicated skin redness, was reduced by $5.30 \%$ and $5.54 \%$, dermal density was increased by $12.08 \%$ and $21.15 \%$, and the wrinkles small value, which indicates the number of skin wrinkles, was decreased by $5.58 \%$ and $8.35 \%$ compared with pretreatment levels. Furthermore, dermal moisture was increased by $23.54 \%, 4.32 \%$, and $6.48 \%$ immediately, 2 , and 4 weeks, respectively, after application of the test materials compared with pre-treatment levels. Conclusion: Toner, lotion, and cream containing JD052 extract were found to have a skin soothing effect on UV-induced skin irritation and to improve dermal density, facial wrinkles, and dermal moisture.
\end{abstract}

Keywords: Scenedesmus deserticola, Microalgae, Skin improvement, Soothing, Antiwrinkle

\section{Introduction}

인간은 나이가 들어감에 따라 인체의 다양한 조직에서 노화 를 경험하는데, 인체의 다양한 노화현상 중 피부의 노화는 가 장 뚜렷하게 시각화 되어 본인과 타인이 인지할 수 있기 때문 에 인간이 가장 민감해하는 노화 현상이라고 할 수 있다.

피부노화의 원인은 크게 내인성 요인과 외인성 요인으로 나눌 수 있다. 내인성 요인은 주로 유전적 요인으로 피부 세 포 및 조직 구조의 변화를 결정한다. 내인성 요인의 대표적 인 예로서, telomere는 진핵세포 염색체 말단에 위치한 구 조물로서, 세포가 생리적으로 노화 될수록 telomere의 단 축이 일어나며, 이는 조직 탈락률에 영향을 줌으로써, 피부
노화에 영향을 주는 것으로 알려져 있다(Nakamura et al., 2002). 외인성 요인은 외부에서 유래된 요인으로 태양 자외 선, 흡연, 과도한 음주, 영양부족, 스트레스 등이 이에 속한 다(Farage et al., 2008). 이러한 외인성 요인 중에서 태양 자외선은 피부노화의 $80 \%$ 이상을 차지하며, 자외선에 의한 노화를 광노화라고 한다(Debacq-Chainiaux et al., 2012; Uitto, 1997). 자외선의 지속적인 노출은 피부세포 내 활성 산소종(reactive oxygen species, ROS)의 생성을 촉진시 켜 산화적 스트레스를 유발하여, 세포의 형질전환, 성장, 분 화 및 세포사멸에 관여하는 주요 단백질인 activator protein 1 (AP-1) 전사인자의 발현을 촉진하여 기질 분해효소인 matrix metalloproteinases (MMPs)를 유도하여 세포외 기 
질(extracellular matrix, $\mathrm{ECM}$ )의 주요 성분인 콜라겐을 파 괴시켜 피부조직을 변화시킴으로써 피부노화를 일으키는 것 으로 알려져 있다(Fisher et al., 1996; Ganceviciene et al., 2012; Helfrich et al., 2008; Lee et al., 2012; Lee et al., 2017; Oh et al., 2004; Pillai et al., 2005).

조류(algae)는 분류학상 다양한 기원을 가지고 있으며, 형 태학적으로 단세포형, 군체형, 사상형, 엽상형, 거대 다세포 형 등으로 구분되며, 크기에 따라 미세조류(microalgae)에 서 미역, 다시마 등의 거대조류(macroalgae)에 이르기까지 매우 다양하다(In et al., 2009). 미세조류는 chlorophyll, carotenoid, phycobilins와 같은 색소를 함유하며 주로 광 합성을 통해 세포 성장과 번식을 하며, 그 종류나 수가 다양 하고 많은 것으로 알려져 있다(Hur et al., 2011). 또한 미세 조류는 환경조건에 따라 폭발적인 증식력을 가지고 있으며, vitamin, carotenoid, polysaccharides와 같은 다양한 유용 물질이 체내에 상대적으로 풍부하게 존재하고, 수소, 탄화수 소, 생화학 연료 등의 생물 산업 소재로서 저비용, 대량생산 이 가능하기 때문에 산업화가 용이하다(Choi et al., 2000; Joo et al., 2011; Oh et al., 2003).

미세조류는 자외선에 의해 유발되는 세포의 손상을 피하 기 위해 자외선에 대한 내성 및 적응성을 높여주는 기작으로 nucleotide excision repair와 같은 DNA 복구 시스템과 자외 선 흡수물질의 형성을 통한 보호 기작이 알려져 있다(Cadet et al., 1992; Carreto et al., 1990; Dunlap \& Chalker, 1986; Han \& Kain, 1992; Han \& Kain, 1993; Sivalingam et al., 1974).

선행연구를 통해 담수미세조류를 대상으로 Bae et al. (2015)에 의해 개발된 자외선 의존적 피부세포 DNA손상 조 절 신규물질 발굴 시스템인 DREAM system (novel DNA repair regulating material discovery system)을 통해 자 외선에 의해 손상될 세포의 보호 능력 및 자외선에 의해 손상 된 세포의 회복 능력이 확인된 JD052 추출물을 이용하여 자 외선 손상 보호용 화장료 원료로서 그 가능성을 확인하였다. 이에 따라 본 연구에서는 29 세 이상의 성인 여성을 대상으로 JD052 추출물을 포함하는 제형(토너, 로션, 크림)을 4주간 적용하여 자외선에 의한 손상 피부 자극 진정효과, 진피치밀 도, 주름, 진피 보습 개선에 대한 인체효능에 대한 효과를 검 증하고자 하였다.

\section{Methods}

\section{JD052 추출물 제조}

본 실험에서 사용한 JD052 (KCTC 18399P)는 한국생
명공학연구원 생물자원센터(Korean Collection for Type Cultures, KCTC, Korea)로부터 동결건조된 균체 $100 \mathrm{~g}$ 을 제공받아 사용하였다. 동결건조된 균체 $20 \mathrm{~g}$ 을 ethyl acetate (Samchun Pure Chemical, Korea) $2 \mathrm{~L}$ 를 이용하여 상온 에서 교반 추출한 후, 여과지(Advantec 5C; Toyo Roshi Kaisha, Japan)를 이용하여 여과하였다. 여과액은 감압 농 축기(Rotavapor R-124; Buchi, Swizerland)로 감압 농축 하여 용매가 모두 제거될 때까지 농축하여 추출물 $2.2 \mathrm{~g} / \mathrm{dry}$ $\mathrm{wt}$ 를 얻었다.

\section{JD052 미세조류 추출물을 함유하는 제형 제조}

JD052 추출물 $2 \mathrm{~g}$ 을 butylene glycol (Oxea, USA) $198 \mathrm{~g}$ 을 첨가하여 교반기(MARK II Model 2.5; Primix, Japan)를 이용하여 $200 \mathrm{rpm}$ 에서 $10 \mathrm{~min}$ 간 용해하여 용액을 제조한 후, 300 mesh 여과포(DS Econo White mesh; DS Mesh, Korea)로 여과하였다. 이후, 여과액 $1 \%$ 를 함유하는 토너, 로 션, 크림 제형을 제조하여 본 실험에 사용하였다(Table 1).

\section{3. 인체효능 평가 및 피시험자의 선정}

본 시험은 헬싱키 선언에 근거한 윤리규정, 식품의약품안 전처의 의약품, 의약외품, 화장품 및 의료기기 검사기관 지정 등에 관한 규정, 의약품 임상시험 관리기준, 화장품 인체적용 시험 및 효력시험 가이드라인, 화장품 표시 광고 실증을 위 한 시험방법 가이드라인, 기능성화장품의 유효성평가를 위한 가이드라인, 보건복지부의 생명윤리 및 안전에 관한 법률에 따라 한국피부과학연구원에 의뢰하여 인체 효능평가를 진행 하였다(KISCS-AFH023-RBO).

상기의 기준에 따라, 자발적으로 모집된 29세 이상의 성 인 여성 중에서 피부질환을 포함하는 급, 만성 신체질환이 없 는 건강한 사람으로서 시험기간 동안 추적관찰이 가능한 사람 22 명을 대상으로 실시하였다.

시험일정은 2016년 8월 26일부터 9월 26일까지 진행되었 으며, 제품사용 0 주, 2 주, 4 주차에 측정하였다.

\section{4. 시험부위}

시험물질의 용법을 기준으로 하여 피시험자의 안면부위는 진피치밀도, 주름개선, 진피 보습개선 평가 부위로 선정하였 으며, 피시험자의 왼쪽 상완의 안쪽 부위는 외부 자외선에 대 한 노출이 적은 부위로서, 자외선에 의한 손상 피부 자극 진 정효과의 평가부위로 선정하였다.

\section{5. 시험물질의 용법 및 용량}

피시험자는 시험기간인 4 주 동안 매일 아침, 저녁 세안 및 세정 후 시험물질 A인 ‘JD052 토너'로 피부결을 정돈하고 시 
Table 1. Ingredients used in the toner, lotion, and cream formulations

\begin{tabular}{|c|c|c|c|}
\hline Formulation & Phase & Ingredient & wt (\%) \\
\hline \multirow{9}{*}{ Toner } & \multirow{5}{*}{ A } & EDTA-2Na & 0.02 \\
\hline & & EDE-Cide Plus & 0.60 \\
\hline & & Glycerin & 5.00 \\
\hline & & Glycereth-26 & 8.00 \\
\hline & & Deionized water & Up to 100.00 \\
\hline & \multirow{3}{*}{ B } & Ethanol & 2.00 \\
\hline & & Fragrance & 0.30 \\
\hline & & Polyethylene glycol-40 hydrogenated castor oil & 0.30 \\
\hline & $\mathrm{C}$ & 1\% JD052 extract in butylene glycol & 1.00 \\
\hline \multirow{14}{*}{ Lotion } & \multirow{5}{*}{ A } & EDTA-2Na & 0.02 \\
\hline & & EDE-Cide Plus & 0.60 \\
\hline & & Glycerin & 5.00 \\
\hline & & Glycereth-26 & 8.00 \\
\hline & & Deionized water & Up to 100.00 \\
\hline & \multirow{7}{*}{ B } & Sorbitan stearate & 0.30 \\
\hline & & Dimethicone & 0.50 \\
\hline & & Glyceryl stearate & 0.50 \\
\hline & & Rheodol MS-165V & 0.50 \\
\hline & & Polysorbate 60 & 1.20 \\
\hline & & MCT oil & 5.00 \\
\hline & & Mineral oil & 10.00 \\
\hline & C & 1\% JD052 extract in butylene glycol & 1.00 \\
\hline & $\mathrm{D}$ & Phenoxyethanol & 0.40 \\
\hline \multirow{18}{*}{ Cream } & \multirow{6}{*}{ A } & EDTA-2Na & 0.02 \\
\hline & & EDE-Cide Plus & 0.60 \\
\hline & & Glycerin & 10.00 \\
\hline & & 1,3-Propanediol & 8.00 \\
\hline & & Carbomer $^{\circledast} 980$ & 0.10 \\
\hline & & Deionized water & Up to 100.00 \\
\hline & \multirow{10}{*}{$\mathrm{B}$} & Sorbitan stearate & 0.30 \\
\hline & & Glyceryl stearate & 0.50 \\
\hline & & Rheodol MS-165V & 0.50 \\
\hline & & MCT oil & 5.00 \\
\hline & & Mineral oil & 10.00 \\
\hline & & Olive oil & 2.00 \\
\hline & & Polysorbate 60 & 1.20 \\
\hline & & Dimethicone & 0.50 \\
\hline & & Tromethamine & 0.10 \\
\hline & & Deionized water & 2.00 \\
\hline & C & 1\% JD052 extract in butylene glycol & 1.00 \\
\hline & $\mathrm{D}$ & Phenoxyethanol & 0.40 \\
\hline
\end{tabular}

EDTA-2Na, ethylenediaminetetraacetic acid disodium salt; EDE-Cide Plus, a preservative composed of octanediol, ethylhexylglycerin, Citrus grandis (grapefruit) seed extract, and Artemisia princeps extract (LABIO, Korea); Rheodol MS-165V, glyceryl stearate and PEG-100 stearate; MCT oil, caprylic/capric triglyceride; JD052, Scenedesmus deserticola JD052. 
험물질 B인 'JD052 로션', 시험물질 C인 'JD052 크림'을 동 일한 양으로 순서대로 안면부위와 왼쪽 상완의 안쪽 지정된 시험부위에 고르게 펴 발라 흡수시켰다. 인체적용시험 기간 중에는 본 시험에 사용된 제품 이외에 시험결과에 영향을 미 칠 수 있는 아이크림, 미백크림, 노화방지용 크림과 같은 기 능성화장품 및 바디보습제의 사용을 일체 금하였으며, 팩이나 마사지 등의 시술도 금하였다.

\section{6. 평가방법}

1) Solar simulator와 ANTERA 3D에 의한 자외선에 의한 손 상 피부 자극 진정효과

자외선에 의한 손상 피부 자극 진정효과 평가를 위하여 solar simulator (Multiport Simulator 601-300W; Solar Light Company, USA)와 ANTERA 3D (Miravex Ireland) 를 적용하였다. 피시험자의 왼쪽 상완의 안쪽 부위를 시 험물질 도포부위와 무도포부위로 나눈 뒤, 지정된 시험부 위에 solar simulator를 이용하여 $38.37 \mathrm{~mJ} / \mathrm{cm}^{2}$ 광량의 $\mathrm{UVA}+\mathrm{UVB}$ 를 $2.5 \mathrm{~s}$ 간격으로 조사하였다. ANTERA $3 \mathrm{D}$ 는 동일한 시험담당자가 모든 피시험자의 왼쪽 상완의 안쪽 부위 의 시험물질 도포부위와 무도포부위를 측정하였으며, 측정의 재현성을 위하여 시험물질 사용 전에 측정한 이미지와 오버 랩시켜 동일부위를 측정하였다. 촬영된 이미지는 ANTERA 3D 전용 소프트웨어인 ANTERA CS software (Miravex, Ireland)를 이용하여 접목시킨 후, 일치된 측정부위를 분석에 사용하였다. 시험물질의 자외선에 의한 손상 피부 자극 진정 효과를 측정하는 값으로는 피부 붉은기를 나타내는 $\mathrm{a}^{*}$ value 를 분석에 사용하였으며, 시험물질 무도포부위와 비교하여 도 포부위의 측정값이 유의하게 $(p<0.05)$ 감소할수록 자외선에 의한 손상 피부 자극 진정효과가 있음을 의미한다. 기기측정 은 시험물질 사용 전(자외선 조사 후)과 2 주 사용 후, 4 주 사 용 후의 시점에서 이루어졌다.

\section{2) DUB ${ }^{\circledR}$ SkinScanner에 의한 진피치밀도 개선 평가}

시험물질의 진피치밀도 개선 평가를 위하여 고해상도의 초 음파를 영상화하는 장치인 DUB ${ }^{\circledR}$ SkinScanner (Taberna pro medicum $\mathrm{GmbH}$, Germany)를 적용하였다. 시험부위에 초음파 검사용 젤을 바르고 $\mathrm{DUB}^{\circledR} \mathrm{SkinScanner}$ 의 probe를 피부와 직각이 되도록 한 후, 동일한 시험담당자가 모든 피시 험자의 왼쪽 눈꼬리 옆 $3 \mathrm{~cm}$ 부위를 동일한 압으로 눌러 진피 치밀도를 측정하였다. 분석범위는 표피 바로 아래에서 피하지 방층 윗부분으로 한정하였으며, 진피치밀도를 의미하는 파라 미터인 intensity를 측정 및 분석하였다. 측정단위는 density 이며, 시험물질 사용 전과 비교하여 측정값이 증가할수록 진 피치밀도가 개선되었음을 의미한다. 기기측정은 시험물질 사
용 전과 2 주 사용 후, 4 주 사용 후의 시점에서 이루어졌다.

3) ANTERA 3D에 의한 주름개선 평가

시험물질의 주름개선 효과를 평가하기 위하여 ANTERA $3 \mathrm{D}$ 를 적용하였다. 동일한 시험담당자가 모든 시험자의 오른 쪽 눈꼬리 주름부위를 측정하였고, 측정의 재현성을 위하여 시험물질 사용 전에 측정한 이미지를 오버랩시켜 동일부위를 측정하였다. 촬영된 이미지는 ANTERA CS Software를 이 용하여 접목시킨 후, 일치된 측정부위를 분석에 사용하였다. 측정값은 측정변수인 indentation index를 이용하여 피부의 주름을 나타내는 wrinkle small 값을 분석에 사용하였다. 시 험물질 사용 전과 비교하여 측정값이 감소할 수록 주름이 개 선되었음을 의미한다. 기기측정은 시험물질 사용 전과 2 주 사 용 후, 4 주 사용 후의 시점에서 이루어졌다.

4) MoistureMeterD Compact에 의한 진피 보습 개선 평가

시험물질의 진피 보습 개선 평가를 위하여 MoistureMeter D Compact (Delfin Technologies, Finland)를 적용하였다. 동일한 시험담당자가 모든 피시험자의 왼쪽 볼 부위에 수직으 로 probe를 접촉하여 $10 \mathrm{~s}$ 동안 수평을 유지시키면서 진피 수 분을 측정하였다. MoistureMeterD Compact는 probe를 통 해 $300 \mathrm{MHz}$ 의 주파수에서 $2 \mathrm{~mm}$ 깊이의 피부조직 유전율 (tissue dielectric constant)을 측정하며, 측정단위는 \%이다. 시험물질 사용 전과 비교하여 측정값이 증가할수록 진피보습 이 개선되었음을 의미한다. 기기측정은 시험물질 사용 전과 2 주 사용 후, 4 주 사용 후의 시점에서 이루어졌다.

5) 피부이상반응 평가

시험부위에서 피부이상 반응인 홍반, 부종, 인설 생성, 가 려움, 자통, 작열감, 뺏뺏함, 따끔거림의 여부를 관찰하고 피 부이상반응이 나타날 시 등급을 표시하여 이에 대한 결과를 작성하였다.

\section{7. 통계분석 방법}

본 시험의 통계처리는 SPSS 17.0 for windows (IBM, USA) 프로그램을 이용하여 분석하였다. 피시험자의 설문지 분석을 위하여 평균, 표준편차, 빈도, 백분율을 실시하였고, 다양한 피부 개선도에 대한 기기측정 결과의 유의한 변화 여 부를 분석하기 위하여 paired $t$-test 분석을 실시하였다. 


\section{Results and Discussion}

\section{1. 자외선에 의한 손상 피부 자극 진정효과}

Solar simulator와 ANTERA 3D를 이용하여 왼쪽 상완의 안쪽 부위의 자외선에 의한 손상 피부 자극 진정효과 개선도 를 분석한 결과, 피부 붉은기를 나타내는 $\mathrm{a}^{*}$ value가 시험물 질 사용 전과 비교하여 2주 사용 후 도포부위에서 $5.30 \%$, 무 도포부위에서 $1.68 \%, 4$ 주 사용 후 도포부위에서 $5.54 \%$, 무 도포부위에서 $3.59 \%$ 가 감소되는 변화를 나타내었다(Table 2 ). 또한 시험물질 무도포부위의 2 주 사용 후, 4 주 사용 후 $\Delta$ $\mathrm{a}^{*}$ value와 비교하여 도포부위의 2 주 사용 후, 4 주 사용 후 $\Delta \mathrm{a}^{*}$ value의 $p$ 값이 각각 0.024 와 0.031 로 통계적으로 유의 하게 나타나 $(p<0.05)$, 시험물질이 자외선에 의한 손상 피부 자극 진정효과에 도움을 주는 것으로 확인되었다.

\section{2. 진피치밀도 개선 평가}

DUB ${ }^{\circledR}$ SkinScanner를 이용하여 왼쪽 눈꼬리 옆 $3 \mathrm{~cm}$ 부
위의 진피치밀도 개선도를 분석한 결과, 진피치밀도가 시험 물질 사용 전과 비교하여 2주 사용 후 $12.08 \%, 4$ 주 사용 후 $21.15 \%$ 가 증가되는 변화를 나타내었다. 또한 시험물질 사용 전과 비교하여 2 주 사용 후, 4 주 사용 후 진피치밀도 값이 통 계적으로 유의하게 나타나 $(p<0.001)$, 시험물질이 진피치밀도 개선에 도움을 주는 것으로 확인되었다(Table 3).

\section{3. 주름 개선 평가}

ANTERA 3D를 이용하여 오른쪽 눈꼬리주름부위의 주 름 개선도를 분석한 결과, 피부의 주름을 나타내는 wrinkle small 값이 시험물질 사용 전과 비교하여 2 주 사용 후 $5.88 \%, 4$ 주 사용 후 $8.35 \%$ 가 감소되는 변화를 나타내었다. 또한 시험물질 사용 전과 비교하여 2 주 사용 후, 4 주 사용 후 wrinkle small 값이 통계적으로 유의하게 나타나 $(p<0.01$, $p<0.001)$, 시험물질이 주름 개선에 도움을 주는 것으로 확인 되었다(Table 4).

Table 2. Evaluation of the skin soothing effect of the toner, lotion, and cream formulations on UV-induced skin irritation using a solar simulator and ANTERA 3D dermal imaging device

\begin{tabular}{|c|c|c|c|c|c|c|}
\hline & \multicolumn{3}{|c|}{ Test group } & \multicolumn{3}{|c|}{ Control group } \\
\hline & Pre treatment & After 2 weeks & After 4 weeks & Pre treatment & After 2 weeks & After 4 weeks \\
\hline$a^{*}$ value & $16.32 \pm 1.82$ & $15.46 \pm 1.23$ & $15.42 \pm 1.22$ & $14.86 \pm 1.49$ & $14.61 \pm 1.49$ & $14.33 \pm 1.10$ \\
\hline$\Delta \mathrm{a}^{*}$ value & & $-0.86 \pm 1.47$ & $-0.90 \pm 1.32$ & & $-0.25 \pm 1.05$ & $-0.53 \pm 1.21$ \\
\hline Improvement rate (\%) & & 5.30 & 5.54 & & 1.68 & 3.59 \\
\hline$p$-value & & $0.024^{*}$ & $0.031^{*}$ & & & \\
\hline
\end{tabular}

The $a^{*}$ value is a measure of skin redness, which was used to analyze the skin soothing effect on UV-induced skin irritation.

$\Delta a^{*}$ value $=$ value after 2 weeks (or 4 weeks)-pre treatment value following UV irradiation.

Improvement rate $(\%)=[$ (post treatment value-pre treatment value $) /$ measured value before the application $\times 100$.

${ }^{*} p<0.05$, paired $t$-test comparing $\Delta \mathrm{a}^{*}$ value of the test group and control group; $\mathrm{M} \pm \mathrm{S}$.D., mean \pm standard deviation.

Table 3. Evaluation of dermal density improvement effects of the toner, lotion, and cream formulations using the DUB ${ }^{\circledR}$ SkinScanner

$(n=22)$

\begin{tabular}{|c|c|c|c|}
\hline & Pre treatment & After 2 weeks & After 4 weeks \\
\hline Dermal density & $23.97 \pm 4.09$ & $26.86 \pm 4.63$ & $29.04 \pm 4.62$ \\
\hline Improvement rate (\%) & & 12.08 & 21.15 \\
\hline$p$-value & & $0.000^{* *}$ & $0.000^{* *}$ \\
\hline
\end{tabular}

Improvement rate $(\%)=[($ post treatment value-pre treatment value $) /$ measured value before the application $] \times 100$.

${ }^{* *} p<0.001$, paired $t$-test; $\mathrm{M} \pm$ S.D., mean \pm standard deviation.

Table 4. Evaluation of the facial wrinkle improvement effects of the toner, lotion, and cream formulations using the ANTERA 3D dermal imaging device

$(n=22)$

\begin{tabular}{|c|c|c|c|}
\hline & Pre treatment & After 2 weeks & After 4 weeks \\
\hline Wrinkles small value & $10.47 \pm 1.80$ & $9.85 \pm 1.66$ & $9.60 \pm 1.61$ \\
\hline Improvement rate (\%) & & 5.88 & 8.35 \\
\hline$p$-value & & $0.002^{*}$ & $0.000^{* *}$ \\
\hline
\end{tabular}

Improvement rate $(\%)=[($ post treatment value - pre treatment value $) /$ measured value before the application $] \times 100$.

${ }^{*} p<0.01,{ }^{* *} p<0.001$, paired $t$-test; M \pm S.D., mean \pm standard deviation. 


\section{4. 진피 보습 개선 평가}

MoistureMeterD Compact를 이용하여 왼쪽 볼 부위의 진 피 보습 개선도를 분석한 결과, 진피 수분이 시험물질 사용 전과 비교하여 1 회 사용 직후 $23.54 \%, 2$ 주 사용 후 $4.32 \%, 4$ 주 사용 후 $6.48 \%$ 가 증가되는 변화를 나타내었다. 또한 시험 물질 사용 전과 비교하여 1 회 사용 직후, 2 주 사용 후, 4 주 사 용 후 진피 수분 값이 통계적으로 유의하게 나타나 $(p<0.001)$, 시험물질이 주름 개선에 도움을 주는 것으로 확인되었다 (Table 5).

\section{5. 피부이상반응 평가}

피시험자를 대상으로 설문조사를 한 결과 홍반, 부종, 인설 생성, 가려움, 자통, 작열감, 뺏뻣함, 따끔거림에 대한 특별한 피부이상반응은 관찰되지 않았다(Table 6).

\section{6. 피부상태 주관적 만족도}

피시험자 22 명을 대상으로 하여 시험물질 사용 후 피부상 태를 설문 조사하였다. 그 결과, 자외선에 의한 피부 자극 진 정 효과에 대해 '그렇다'와 '매우 그렇다'는 답변이 4 주 사용 후 $45.5 \%$ 와 $9.1 \%$ 로 비교적 높게 나타났다. 피부 탄력 개선 에 대해서는 '그렇다'와 '매우 그렇다'의 답변이 4 주 사용 후
63.6\%와 27.3\%로 매우 높게 나타났다. 주름 개선 평가에 대 한 문항에서는 '그렇다'와 '매우 그렇다'의 답변이 4 주 사용 후 $54.6 \%$ 와 $22.7 \%$ 로 매우 높게 나타났으며, 피부 보습 관련 문 항에서는 '그렇다'와 '매우 그렇다'의 답변이 4 주 후 $36.4 \%$ 와 $54.5 \%$ 로 피시험자의 대부분이 만족감을 느끼는 것으로 나타 났다. 세안 후 피부 속 당김 관련된 문항에서는 '그렇다'와 '매 우 그렇다'의 답변이 $31.8 \%$ 와 $59.1 \%$ 로 매우 높은 만족감을 나타내었다(Table 7).

\section{Conclusion}

본 연구에서는 JD052 추출물을 포함하는 토너, 로션, 크 림을 제조하여 평균연령이 42.68 세의 피시험자 22 명을 대 상으로 하여 자외선에 의한 손상 피부 자극 진정효과, 진피 치밀도, 주름, 진피 보습 개선에 대한 인체적용 시험을 실 시하였다. Solar simulator와 ANTERA 3D를 이용하여 자 외선에 의한 손상 피부 자극 진정효과 개선도를 분석한 결 과, 시험물질 무도포부위와 비교하여 통계적으로 유의한 수 준으로 $(p<0.05), 2$ 주 사용 후 $5.30 \%, 4$ 주 사용 후 $5.54 \%$ 의 자외선에 의한 손상 피부 자극 진정효과 개선율을 나타

Table 5. Evaluation of the dermal moisture improvement effects of the toner, lotion, and cream formulations using the MoistureMeterD Compact

\begin{tabular}{|c|c|c|c|c|}
\hline & Pre treatment & Immediately after & After 2 weeks & After 4 weeks \\
\hline Dermal moisture (mean \pm S.D.) & $42.090 \pm 5.420$ & $52.000 \pm 5.140$ & $43.910 \pm 4.740$ & $44.820 \pm 4.970$ \\
\hline Improvement rate (\%) & & 23.540 & 4.320 & 6.480 \\
\hline$p$-value & & $0.000^{* *}$ & $0.000^{* *}$ & $0.000^{* *}$ \\
\hline
\end{tabular}

Improvement rate $(\%)=[($ post treatment value-pre treatment value $) /$ measured value before the application $] \times 100$.

${ }^{* *} p<0.001$, paired $t$-test; $M \pm S$.D., mean \pm standard deviation.

\begin{tabular}{lcc}
\hline Abnormal response & After 2 weeks & After 4 weeks \\
Erythema & 0 & 0 \\
Swelling (edema) & 0 & 0 \\
Scaling (epidermis) & 0 & 0 \\
Itching & 0 & 0 \\
Stinging (pain) & 0 & 0 \\
Burning & 0 & 0 \\
Tightness & 0 & 0 \\
Pricking & 0 & 0 \\
\hline
\end{tabular}

0, none; 1 , mild; 2 , moderate; 3 , severe. 
냈다(Table 2). DUB ${ }^{\circledR}$ SkinScanner를 이용하여 진피치밀 도 개선도를 분석한 결과, 시험물질 사용 전과 비교하여 통계 적으로 유의한 수준으로 $(p<0.001), 2$ 주 사용 후 $12.08 \%, 4$ 주 사용 후 $21.15 \%$ 의 진피치밀도 개선율을 나타냈다(Table 3). ANTERA 3D를 이용하여 주름 개선도를 분석한 결과, 시험물질 사용 전과 비교하여 통계적으로 유의한 수준으로 ( $p<0.01), 2$ 주 사용 후 $5.88 \%, 4$ 주 사용 후 $8.35 \%$ 의 주름 개 선율을 나타냈다(Table 4). MoistureMeterD Compact를 이 용하여 진피 보습 개선도를 분석한 결과, 시험물질 사용전과 비교하여 통계적으로 유의한 수준으로 $(p<0.001) 1$ 회 사용 직 후 $23.54 \%, 2$ 주 사용 후 $4.32 \%, 4$ 주 사용 후 $6.48 \%$ 의 진피 보습 개선율을 나타냈다(Table 5). 이러한 결과들은 JD052 추출물이 자외선에 의한 손상 피부 자극 진정효과와 진피치밀 도 개선을 통한 피부탄력, 주름 개선 및 진피 보습 개선에 뛰 어난 효과를 가지고 있음을 본 임상시험을 통해서 확인할 수 있었다.
이와 함께 피시험자의 시험물질 사용 후 피부상태를 설문 조사한 결과, 자외선에 의해 손상된 피부에 대한 진정효과에 대해서는 2 주 사용 후와 4 주 사용 후의 '그렇다'와 '매우 그렇 다'의 긍정적인 답변이 $68.2 \%$ 와 $54.6 \%$ 로 비교적 높게 나타 났으나, 4 주 사용 후의 긍정적인 평가가 다소 감소하는 답변 이 나타났다. 피부 속 탄력에 대해서도 2 주 사용 후와 4 주 사 용 후의 긍정적인 답변이 $81.8 \%$ 와 $90.9 \%$ 매우 높게 나타났 다. 눈가주름 개선에 대해서는 2 주 사용 후와 4 주 사용 후의 긍정적인 답변이 $50.0 \%$ 와 $77.3 \%$ 로 나타났으며, 피부 보습 에 대해서는 2 주 사용 후와 4 주 사용 후의 긍정적인 답변이 $91.0 \%$ 와 $90.9 \%$ 로 매우 높게 나타났다. 세안 후 피부의 속당 김에 대해서도 2 주 사용 후와 4 주 사용 후의 긍정적인 답변이 $86.4 \%$ 와 $90.9 \%$ 로 나타나 자외선에 의한 피부 진정을 제외하 고는 모든 설문에서 사용기간이 길수록 그 만족도가 증가함을 확인할 수 있었다(Table 7).

본 연구를 통해 자외선에 대한 세포보호 효과 및 손상된 세

Table 7. Facial skin condition following application of the test materials

\begin{tabular}{|c|c|c|c|c|c|}
\hline \multirow{2}{*}{ Question } & & \multicolumn{2}{|c|}{ After 2 weeks } & \multicolumn{2}{|c|}{ After 4 weeks } \\
\hline & & Frequency & $\%$ & Frequency & $\%$ \\
\hline \multirow{5}{*}{$\begin{array}{l}\text { Skin irritation induced by UV rays } \\
\text { was relieved rapidly }\end{array}$} & Strongly disagree & 0 & 0.0 & 0 & 0.0 \\
\hline & Disagree & 1 & 4.5 & 3 & 13.6 \\
\hline & Neutral & 6 & 27.3 & 7 & 31.8 \\
\hline & Agree & 14 & 63.7 & 10 & 45.5 \\
\hline & Strongly agree & 1 & 4.5 & 2 & 9.1 \\
\hline \multirow{5}{*}{ Skin became elastic } & Strongly disagree & 0 & 0.0 & 0 & 0.0 \\
\hline & Disagree & 0 & 0.0 & 0 & 0.0 \\
\hline & Neutral & 4 & 18.2 & 2 & 9.1 \\
\hline & Agree & 15 & 68.2 & 14 & 63.6 \\
\hline & Strongly agree & 3 & 13.6 & 6 & 27.3 \\
\hline \multirow{5}{*}{$\begin{array}{l}\text { Skin wrinkles around eyes were } \\
\text { decreased }\end{array}$} & Strongly disagree & 0 & 0.0 & 0 & 0.0 \\
\hline & Disagree & 0 & 0.0 & 0 & 0.0 \\
\hline & Neutral & 11 & 50.0 & 5 & 22.7 \\
\hline & Agree & 9 & 40.9 & 12 & 54.6 \\
\hline & Strongly agree & 2 & 9.1 & 5 & 22.7 \\
\hline \multirow{5}{*}{ Skin became moist } & Strongly disagree & 0 & 0.0 & 0 & 0.0 \\
\hline & Disagree & 1 & 4.5 & 0 & 0.0 \\
\hline & Neutral & 1 & 4.5 & 2 & 9.1 \\
\hline & Agree & 12 & 54.5 & 8 & 36.4 \\
\hline & Strongly agree & 8 & 36.5 & 12 & 54.5 \\
\hline \multirow{5}{*}{$\begin{array}{l}\text { Tight skin feeling after washing } \\
\text { face was relieved }\end{array}$} & Strongly disagree & 0 & 0.0 & 0 & 0.0 \\
\hline & Disagree & 1 & 4.5 & 0 & 0.0 \\
\hline & Neutral & 2 & 9.1 & 2 & 9.1 \\
\hline & Agree & 15 & 68.2 & 7 & 31.8 \\
\hline & Strongly agree & 4 & 18.2 & 13 & 59.1 \\
\hline
\end{tabular}


포의 회복 능력이 확인된 JD052 추출물을 화장품 제형에 적 용하였을 때, 자외선에 의한 피부 자극 진정효과, 진피치밀 도, 주름 진피 보습 개선에 도움을 주는 것을 확인하였다.

\section{Acknowledgements}

본 연구는 보건복지부의 "글로벌화장품신소재, 신기술연구 개발지원"사업(과제번호 $\mathrm{HN} 13 \mathrm{C0080)}$ 으로 수행된 연구결과 입니다.

\section{References}

Bae S, An IS, An S. Development of a high-throughput screening system for identification of novel reagents regulating DNA damage in human dermal fibroblasts. Acta Pharmaceutica, 65: 331-341, 2015.

Cadet J, Anselmino C, Douki T, Voituriez L. Photochemistry of nucleic acids in cells. Journal of Photochemistry and Photobiology B: Biology, 15: 277-298, 1992.

Carreto Jl, Carignan MO, Daleo G, De Marco SG. Occurrence of mycosporine-like amino acids in the redtide dinoflagellate Alexandrium excavatum: UVphotoprotective compounds? Journal of Plankton Research, 12: 909-921, 1990.

Choi JS, Lee WK, Son BW, Kim DS, Choi HD, Choi JS, Jung $\mathrm{JH}, \mathrm{Im} \mathrm{KS}$, Choi WC. Screening on radical scavenging activity of marine microalgae. Korean Journal of Pharmacognosy, 31: 252-255, 2000.

Debacq-Chainiaux F, Leduc C, Verbeke A, Toussaint O. UV, stress and aging. Dermato-Endocrinology, 4: 236-240, 2012.

Dunlap WC, Chalker BE. Identification and quantitation of near-UV absorbing compounds (S-320) in a hermatypic scleractinian. Coral Reefs, 5: 155-159, 1986.

Farage MA, Miller KW, Elsner P, Maibach HI. Intrinsic and extrinsic factors in skin ageing: a review. International Journal of Cosmetic Science, 30: 87-95, 2008.

Fisher GJ, Datta SC, Talwar HS, Wang ZQ, Varani J, Kang S, Voorhees JJ. Molecular basis of sun-induced premature skin ageing and retinoid antagonism. Nature, 379: 335-339, 1996.

Ganceviciene R, Liakou Al, Theodoridis A, Makrantonaki E, Zouboulis CC. Skin anti-aging strategies. DermatoEndocrinology, 4: 308-319, 2012.
Han T, Kain JM. Blue light sensitivity of UV-irradiated young sporophytes of Laminaria hyperborea. Journal of Experimental Marine Biology and Ecology, 158: 219230, 1992.

Han T, Kain JM. Blue light photoreactivation in ultravioletirradiated young sporophytes of Alaria esculenta and Laminaria saccharina (Phaeophyta). Journal of Phycology, 29: 79-81, 1993.

Helfrich YR, Sachs DL, Voorhees JJ. Overview of skin aging and photoaging. Dermatology Nursing, 20: 177-183, 2008.

Hur YB, Jeon CY, Cho KC, Hur SB. Ingestion size of food microalgae of the pacific oyster Crassostrea gigas larvae. The Korean Journal of Malacology, 27: 307-315, 2011.

In MJ, Kim YM. Effect of cell lytic enzyme treatment on the extraction yield in production of microalgae extract. Journal of Foodservice Industry \& Management Research, 5: 83-93, 2009.

Joo DS, Kim KW, Cho SY. Physiological properties of extracts and the chemical composition of Tetraselmis sp. JK46 cultured with deep seawater. Korean Journal of Fisheries and Aquatic Sciences, 44: 1-7, 2011.

Lee YR, Noh EM, Han JH, Kim JM, Hwang JK, Hwang BM, Chung EY, Kim BS, Lee SH, Lee SJ, et al. Brazilin inhibits UVB-induced MMP-1/3 expressions and secretions by suppressing the NF-KB pathway in human dermal fibroblasts. European Journal of Pharmacology, 674: 80-86, 2012.

Lee NK, Ku JE, Han HS. Cytoprotective and anti-inflammatory effects of 6-shogaol on human dermal fibroblasts. Asian Journal of Beauty and Cosmetology, 15: 367376, 2017.

Nakamura K, Izumiyama-Shimomura N, Sawabe M, Arai T, Aoyagi Y, Fujiwara M, Tsuchiya E, Kobayashi Y, Kato M, Oshimura $\mathrm{M}$, et al. Comparative analysis of telomere lengths and erosion with age in human epidermis and lingual epithelium. Journal of Investigative Dermatology, 119: 1014-1019, 2002.

Oh HM, Choi A, Mheen TI. High-value materials from microalgae. Microbiology and Biotechnology Letters, 31: 95-102, 2003.

Oh JH, Chung AS, Steinbrenner H, Sies H, Brenneisen P. Thioredoxin secreted upon ultraviolet a irradiation 
modulates activities of matrix metalloproteinase-2 and tissue inhibitor of metalloproteinase-2 in human dermal fibroblasts. Archives of Biochemistry and Biophysics, 423: 218-226, 2004.

Pillai S, Oresajo C, Hayward J. Ultraviolet radiation and skin aging: roles of reactive oxygen species, inflammation and protease activation, and strategies for prevention of inflammation-induced matrix degradation-a review.
International Journal of Cosmetic Science, 27: 17-34, 2005.

Sivalingam PM, Ikawa T, Yokohama Y, Nisizawa K. Distribution of a 334 UV-absorbing-substance in algae, with special regard of its possible physiological roles. Botanica Marina, 17: 23-29, 1974.

Uitto J. Understanding premature skin aging. The New England Journal of Medicine, 337: 1463-1465, 1997. 


\section{국문초록}

\section{자외선 손상 피부에 대한 Scenedesmus deserticola JD052 추출물의 효능}

백준석, 진세은, 강승혜, 박찬선, 정재훈, 이상원, 김영수*

(주라비오 소재과학연구소, 서울, 한국

목적: 본 연구는 Scenedesmus deserticola JD052 (JD052) 추출물을 포함하는 토너, 로션, 크림의 자외선에 의한 손상 피부 자극 진정효과와 진피치밀도, 주름, 진피 보습 개선에 대한 인체 효능을 평가하는 것을 목적으로 한다. 방법: 선정기준 및 선정제외기 준에 기초하여 29 세 이상의 성인 여성 22 명을 피시험자로 선정하였다. 피시험자는 시험기간인 4 주 동안 매일 아침, 저녁으로 세안 및 왼쪽 상완 부위를 세정 후, JD052 추출물이 함유된 시험물질인 토너, 로션, 크림을 동일한 양으로 순서대로 안면부위와 왼쪽 상 완의 지정된 시험부위에 고르게 펴 발라 흡수시켰다. 시험물질의 자외선에 의한 손상 피부 자극 진정효과를 평가하기 위하여 solar simulator와 ANTERA 3D를 적용하여 측정하였으며, 진피치밀도 개선평가는 $\mathrm{DUB}^{\circledR} \mathrm{SkinScanner}$ 를 이용하여 측정하였다. 주름 개 선 평가는 ANTERA $3 \mathrm{D}$ 를 적용하여 측정하였으며, 진피 보습 개선 평가는 MoistureMeterD Compact를 이용하여 측정하였다. 결 과: 시험물질 사용 전과 비교하여 2주 및 4주 사용 후, 피부 붉은기를 나타내는 a* value가 각각 $5.30 \%, 5.54 \%$ 감소하였으며, 진피 치밀도는 각각 $12.08 \%, 21.15 \%$ 증가하였다. 피부 주름을 나타내는 wrinkles small value는 각각 $5.58 \%, 8.35 \%$ 감소하였으며, 진 피 수분은 시험물질 사용 전과 비교하여, 1 회 사용 직후, 2 주 및 4 주 사용 후가 각각 $23.54 \%, 4.32 \%, 6.48 \%$ 로 증가되었다. 결론: $\mathrm{JD} 052$ 추출물을 포함하는 토너, 로션, 크림은 자외선에 의한 손상 피부 자극 진정효과와 진피치밀도, 주름, 진피 보습 개선에 도움 을 주는 것으로 사료된다.

핵심어: Scenedesmus deserticola, 미세조류, 피부개선, 진정, 항주름

본 연구는 보건복지부의 “글로벌화장품신소재, 신기술연구개발지원”사업(과제번호 $\mathrm{HN} 13 \mathrm{C0080)으로} \mathrm{수행된} \mathrm{연구결과입니다.}$

\section{참고문헌}

오희목, 최애란, 민태익. 미세조류 유래 고부가 유용물질. 한국미생물·생명공학회지, 31: 95-102, 2003.

이나경, 구정은, 한효선. 인간진피섬유아세포에서 6-shogaol의 세포보호 및 항염증 효과. 아시안뷰티화장품학술지, 15 : 367-376, 2017.

인만진, 김용문. 세포벽 분해효소의 사용이 미세조류 추출물의 수율에 미치는 영향. 외식산업경영연구, 5: 83-93, 2009.

주동식, 김광우, 조순영. 해양심층수로 배양한 해양미세조류 Tetraselmis sp. JK-46의 성분 조성 및 생리활성. 한국수산과학 회지, 44: 1-7, 2011.

최진석, 이원갑, 손병화, 김동수, 최홍대, 최재수, 정지형, 임광식, 최원철. 해양미세조류의 라디칼소거활성 검색. 생약학회지, 31: 252-255, 2000. 


\section{中文摘要}

\section{Scenedesmus deserticola JD052提取物对紫外线损伤皮肤的作用}

白俊碩，秦世恩，姜丞德，朴璨宣，鄭在訓，李相元，金瑩洙 ${ }^{*}$

LABIO 素材科学研究所, 首尔, 韩国

目的: 探索含有Scenedesmus deserticola JD052（JD052）提取物的化妆水，乳液和面霜对UV诱导损伤皮肤的皮肤刺激 镇静作用以及改善皮肤密度, 皱纹和皮肤保湿作用的效果。方法: 根据预先设定的纳入和排除标准, 选出了年龄在29岁 以上的22名女性受试者。每个早晚各4周, 每个受试者每天洗脸和左上臂, 然后按照化妆水, 乳液和面霜顺序在这些部位 上涂抹相同量。为评价紫外线损伤皮肤的镇静效果, 使用solar simulator和ANTERA 3D来进行测定; 皮肤密度改善效果 利用DUB ${ }^{\circledR}$ SkinScanner来测定; 面部皱纹改善利用ANTERA 3D来测定; 皮肤水分改善效果利用MoistureMeterD Compact 来测定。结果：使用试验材料2周和4周后，皮肤的a“值分别降低了 $5.30 \%$ 和 $5.54 \%$; 皮肤密度分别增加了 $12.08 \%$ 和 $21.15 \%$; 显示皱纹的wrinkles small value分别降低了 $5.58 \%$ 和 $8.35 \%$ 。此外，施用试验材料后，皮肤水分分别比施用前 相比，分别提高了 $23.54 \%$ (使用1次后），4.32\%（2周）和6.48\%（4周）。结论: 含有JD052提取物的化妆水，乳液和 面霜被发现对紫外线诱导的皮肤刺激具有皮肤舒缓作用，并改善皮肤密度，面部皱纹和皮肤水分。

关键词: Scenedesmus deserticola, 微藻, 皮肤改善, 镇静, 抗皱纹 